\title{
Tropical Flânerie \& the Creative Asian City: a perambulation of literature
}

\author{
Sneha Chaudhury \& Anita Lundberg
}

James Cook University Singapore

\section{Abstract}

The flâneur became a literary figure of $19^{\text {th }}$ century Paris and was taken up as a theoretical figure in the early $20^{\text {th }}$ century. During these periods the city was undergoing massive social, architectural and infrastructural change. Today, the notion of the flâneur is experiencing a renaissance as cities are undergoing significant restructuring towards creative industries and economies.

At the same time, two distinctive aspects of the theory of the flâneur are facing critique. One is to do with geography. The theory is based on cities of the global north, such as Paris, London and New York, and thus inherently entwined with the colonial metropole. The other aspect concerns gender. The flâneur invokes a masculine gaze, and the possibility of a female flâneuse remains under debate.

The current century has been witness to the rapid growth of cities, including in the tropics and Asia. This literature review - in the style of a perambulation - explores flânerie with examples of tropical Asian cities. Singapore is of special interest as it strives to become a 'renaissance city' - a global city of the arts, based on creative industries and economies. As a theory and method of critically meandering the creative city, flânerie offers a way of engaging and contributing to an ethnography of urban life. Furthermore, such a method may usefully rework the notion of the gaze of the flâneur to include the use of photography.

Keywords: flânerie, flâneuse, flâneur, ethnography, creative city, Singapore, Asian city

here is a need to study creativity in relation to cities. Charles Landry (1994, p. 11) states that historically, creativity has always been the lifeblood of the city. Cities have required creativity in order to work as markets and centers of trade and production, with their 
critical mass of talented human resources. Cities have been the predominant places where cultures mix and where interaction inspires new ideas, artifacts and institutions. And they have been the places that allow people room to live out their ideas and express themselves.

Today, as with the case of Singapore, many of the world's cities are facing a significant transition. Old industries are disappearing as added value to products is created less through what we manufacture and more through the application of new knowledge to products, processes and services. As Richard Florida argues: "creativity has become the principal driving force in the growth and development of cities, regions, and nations. Cities are cauldrons of creativity. They have long been the vehicles for mobilizing, concentrating, and channeling human creative energy" (2002, p. 27).

Singapore is on a quest to become such a 'Renaissance City'. The government has identified that Creative Societies are multi-billion dollar industries. The vision and plan for the promotion of arts and culture is first, to establish Singapore as a global arts city conducive to creative, knowledge-based industries and talent; and second, to strengthen national identity and belonging among Singaporeans by nurturing an appreciation of shared heritage (National Arts Council, 2000, p.4). However, it remains to be seen if this strategic plan - a panoptic vision can translate to everyday practices on the street.

Singapore, adhering to quantitative indexes to measure the city's success, is ticking off the boxes for the makings of a global creative city. It has all the resources in terms of finance, infrastructure, global trade and a diverse knowledgeable population. However, there is concern that quantitative methods cannot capture the fluidity necessary for a creative city of the people.

We propose that flânerie offers a way to inherently critique the predominant quantitative metrics. In very simple terms, flânerie requires strolling in the city to experience it, being simultaneously an observer and participating in the creative life of the metropolis. In this regard, the theory and method offers another dimension for ethnographic practice in urban anthropology, and furthermore extends notions of participant-observation to photographic praxis. Flânerie allows the fluidity to engage with and understand the city going through creative transition from the ground level.

Indeed, the figure and theory of the flâneur has historically arisen during periods of metropolitan transition. The literary figure was notable in $19^{\text {th }}$ century Paris, a time when the city was undergoing massive changes after Napoléon III commissioned the architectural and infrastructural remodeling undertaken by Baron Haussman. During this period Charles Baudelaire included the figure of the flâneur in his writings, and called for artistic persons to 
immerse themselves in the quotidian movements of the city streets. Again, in the early $20^{\text {th }}$ century, Walter Benjamin brought the figure of the flâneur - and the covered Paris arcades through which he sauntered - into his cultural critique of the social changes enforced by industrialisation and capitalism. In the $21^{\text {st }}$ century, the figure and theory of the flâneur is experiencing a renaissance as cities are transiting to creative industries and economies.

However, the theory has been critiqued on two points. One, that it is based on cities in the global north - such as Paris, London and New York and thus is geo-historically entwined with the colonial metropole. And two, that it inherently invokes a masculine gaze - thus women's lack of freedom to wander streets and gaze freely without being noticed, harassed, or negatively labelled, problematises the possibility of the female flâneuse.

We contend that tropical flânerie - and the flâneuse tropique - can offer important critical perspectives to exploring and theorising the emerging creative city. This is particularly pertinent to the study of Singapore as it strives to become to a global creative metropolis, but likewise extends to other tropical cities - so many of which were former colonial outposts - as they undergo massive population growth and economic and industrial change.

The following literature review is a perambulation through significant texts and perspectives; a guide for flânerie in the rising creative city, especially in tropical Asia. The literature has been ordered under the following themes: the creative city; the flâneur in classical literature; the contemporary flâneur in tropical Asia; the female flâneuse; flânerie as ethnographic method; and visual flânerie through photography.

\section{The Creative City}

Charles Landry in The Creative City (1994), articulated how cities may be improved both physically and also for people's lived experience. Creativity is a very important part of that equation. In the case of Singapore there is a need to understand the city as space, alive and peopled. In his book, The Location of Culture (1994), Homi Bhabha analysed the notion of the "hybrid" and 'in between'; the 'third space' as the liminal realm for cultural confluence and the birth of a new, shared, identity in a postcolonial society. Often the reality of the post colony society (after the colonizers have left) is that the government continues to implement the old colonial structure and perspective; what is required for the realisation of a postcolonial city is the revitalisation of the population and culture. New cultural identities emerge as a result of negotiation and navigation of meaning and space. With change, comes an inherent opposition, and the resulting turmoil produces a fertile space for creativity to flourish. The conflicts, both 
within and outside the individual, may result from the confusion of not feeling at home in one's own home. This confusion and the concomitant search for identity breeds the creativity that comes from the cracks in the city's planned structure - metaphorically, its pavements. It is these interstitial spaces that the theorist Michel de Certeau (2011) articulates in his writings on creativity and everyday life.

A majority of Singapore's population falls under what Richard Florida (2002) coined the "creative class"; those people who are employed in occupations that are, to a significant extent, associated with "the creation of meaningful new forms" (2002, p.10). They are found in a variety of fields, from engineering to theater, biotech to education, architecture to small business. They have already had a huge economic impact. Florida $(2002,2012)$ maintained that cities that fail to attract, maintain, and facilitate the activities of the creative class (including LGBTQ and "bohemians") are much less likely to achieve high levels of prosperity and economic growth, and generate a high tax base.

Today, Singapore is an economic giant and is aiming to become a creative city ranking alongside London, Paris and New York. How to define a creative city is becoming increasingly important as the world moves further into a postindustrial age. Åke Andersson and David Emanuel Andersson in Creative Cities and the New Global Hierarchy (2015) notably argue that deviant and psychotic conditions are a key benefit for the creation and maintenance of a creative arena. This conflicts with Singapore's strong insistence on stability and order. However, it can be argued that conflicts of ideas need not always exist in order to harbor creativity; overstability actually provides a basis for the creation of a rebellious, paradoxical creativity.

Significantly, Andersson and Andersson (2015) ascertain that the movement towards creative cities is not linear; rather, we suggest, it is rhizomatic in nature (see Lundberg, 2016, pp.111112). This movement is not restricted to just a few select cities, there is a global recognition of the need for creative and innovative practices - including cultural expressions. In order to help transform cities into creative spaces, there is a shift in government policies across the world to promote such change.

As a way of understanding how governmental policies translate and transition at the street level, we argue that the theory and method of the flâneur is pertinent.

\section{The flâneur in classic literature}

The flâneur famously appeared in the writings of Charles Baudelaire; the flâneur was a bourgeois man of means with free time on his hands to wander, observe and report the daily 
happenings and changes in the kaleidoscopic city of Paris of the $19^{\text {th }}$ century. Dandy and aesthete, the flâneur was both critical and in awe of the arcades which were symbolic of material culture and modernity of the time. "What strange phenomena we find in a great city, all we need do is stroll about with our eyes open. Life swarms with innocent monsters" (quoted in Wolfe, 2017, p. 89).

Baudelaire wrote The Painter of Modern Life (1964[1863]), in which the figure of the flâneur appears, at a time when Paris was going through massive architectural and structural change at the instigation of Napoléon III who commissioned Baron Haussman to undertake the city's remodeling. Baudelaire's flâneur is in a sense a distant observer looking in. The bohemian and outsider, simultaneously participating in the changing cityscape; lover of the crowds and interested in the whole world. Baudelaire's work inspired Walter Benjamin's The Arcades Project (2003 [1940]).

Walter Benjamin was extremely inspired by the arcades of Paris. His unfinished magnum opus spans over twenty years of the rise and fall of the arcades. His work explored the anaesthesialike state induced by life in the modern city and critiques the fetishisation of commodity and consumer culture; but he also posits a more expressive way of experiencing the city through the senses of sight, smell and sound by walking or wandering uninhibitedly - both aspects that were embodied in Baudelaire's poetry and prose. Benjamin also recognised Baudelaire's critical influence on new technologies such as photography - he denounced the daguerreotype as lacking sentiment. In The Arcades Project, Benjamin explored a variety of disciplines - history, politics, philosophy, architecture and psychology are just a few of the overarching ones. His work is a vast collection of notes and therefore is cryptic and left open to interpretation. They offer a wandering.

Susan Buck-Morss, in her book The dialectics of seeing: Walter Benjamin and the Arcades Project (1991), uses the term 'blueprint' in relation to Benjamin's work which seems oxymoronic as his works were a bricolage of 'ragpickings' (Benjamin, 2003) - notes and recountings - of his experiences while walking through the arcades of Paris. His peregrinations are in no particular direction; a combination of the wanderings of his mind and unplanned walking in the streets. Buck-Morss, on the other hand, gives The Arcades Project a structure; and in translating and reconstructing Benjamin's (2003) "rag picking" of the arcades, she allows for his seminal works to be more accessible to a wider audience. The use of images in her book supports her explanatory analysis and offers the reader a visual understanding of Benjamin's explorations.

While blueprints and structures were not part of the vocabulary of Baudelaire and Benjamin, the French cultural theorist, Michel de Certeau in The Practice of Everyday Life (2011 [1984]), 
especially the often quoted chapter 'Walking in the City' (p. 91-111), wrote about escaping such structures and blueprints. His work speaks of the central planner's perspective and the panoptic bird's eye view of the city; such a view allows the planner to survey and surveil the city. Cities are conceived as planned and structured spaces. However, as de Certeau argues, without the people, a city's infrastructural efficiency, beauty and aesthetic are rendered meaningless. A city's spaces are defined by the people walking through them and without people the space becomes devoid of meaning. The meaning of the space is as fleeting as the movement of pedestrians. The city merely provides the infrastructural stimuli for creativity, which emerges through the cracks in the sidewalks.

These classic texts about walking in the city are apposite to contemporary contexts. Like creativity, flâneurie is an organic process and these texts provide a foundation for the meanderings which will help the contemporary flâneurlflâneuse stumble upon those small spaces of creativity which lie outside the purview of the panoptic gaze.

Despite a renaissance of interest in the theory of the flâneur, there remains a paucity of application of the theory in cities of the tropics. The numerous notable works about the flâneur that have been written about Western cities and analysed through these Anglo-European spaces include: Ackland (2017), Boutin (2016), Coates (2017), Dreyer \& McDowall (2012), Elkin (2017), Fulford (2013), Garcia-Sanchez (2013), Goldstein (2008), Gluck (2003), Hessel, Benjamin \& DeMarco (2017), Jenks \& Neves (2011), Kramer \& Short (2011), Laschinger (2009), Lauster (2007), Mallan (2012), Soukup (2012;), Suarez (2015), Vainshtein (2017), Watson (2005), White (2001), Wrigley (2014), and Yang (2012).

Extending this space of analysis to the tropics is the theme of the next section on the tropical flâneur.

\section{The contemporary flâneur in tropical Asia}

In the article, 'Benjamin's Arcades Project today: From the European metropolis to the global city' (2011), Rolf Goebel explores global cities and their relation to one another as central nodes in networks of international trade, tourism and art. However, he notes that the huge transformative processes of our time brought by globalisation cannot be properly understood until they are grasped through the conceptual vocabulary of culture. He specifies that "culture" is not the single or even the dominant key to globalisation, but that "these transformations change the very fabric of cultural experience and, indeed, affect our sense of what culture actually is in the modern world" (2011, p. 489). 
Goebel (2011) argues that $19^{\text {th }}$ century Paris relied on non-Western imagery to help form its European identity. "Benjamin's Paris, the western capital of the $19^{\text {th }}$ century, reflects a crucial transition with respect to European urban modernity, where culture is still tied to local traditions even while already being affected by agents - world exhibitions, panoramas, the display and consumption of "foreign" commodities - that begin to break up the "natural" identity of culture and the local" (Goebel, 2011, p. 489). He then proceeds to use Benjamin's work for analysing representations of non-Western cities. Juxtaposed against Benjamin's Paris is the image of modern day Hong Kong, an Asian city inherently transient and unstable due to historic and political reasons. Hong Kong serves as a particularly intriguing example for rereading Benjamin's critique of urban phantasmagoria in terms of global interconnectivity (Goebel, 2011, p. 492).

Significantly, Geobel subscribes to Homi Bhaba's theory of hybrid spaces, of cities trying to navigate their post colonial identities. In the process of globalization cross-pollination of cultures is inevitable. The article concludes with the critique that Hong Kong's complex hybrid 'placeless' (Goebel, 2011, p. 493) space has lead it to become an unimaginative city aping the West, unsure of how to navigate its cultural hybrid space. The people of Hong Kong have traditionally defined themselves primarily "in terms of what they were not", namely mainland communists. Their elusive and tenuous sense of self-identity has derived a culture of consumerist luxury, entertainment and good education. In Hong Kong, the production of such a transcultural image clashes with the realities of an increasingly congested living space, compounded by the stark social differences between international business people and migrant labourers, many illegal, from less developed countries. Reflecting Benjamin's critique of bourgeois modernity, Goebel observes Hong Kong's "postcolonial hypermodernity that compensates for the lack of cultural specificity" (2011, p. 493).

Among the network of global cities, Singapore has risen quickly to tick off the list of criteria to be acknowledged as a global city. However, according to the criteria proposed by Andersson and Andersson (2015) what it lacks is the fluidity required to make it a truly creative city, partly because of its strict policies and government regulations. It has also been well observed that planners, in a structural sense, dictate the art of walking.

Daniel P. S. Goh in his article, 'Walking the Global City: The Politics of Rhythm and Memory in Singapore' (2014), takes a close look at the politics of walking in this city. He notes that the government has tried to inculcate an appreciation for its shared heritage among Singaporeans by introducing heritage trails around major heritage sites. This, however, has created a space for local artists to challenge or critique the planned system. The heritage trails are also evidence of the cultural pluralism that exists in Singapore. The city is an international symbol of 
cultural harmony. However, the author argues that this is part of the cultivated image of Singapore which has come about after years of effort by the government to maintain peace. The lack of uprisings does not make it free of racism. Such conflicts are common in hybrid spaces like Singapore. Trying to create a shared identity is problematic in a culturally diverse space.

Goh (2014) uses the theories of Benjamin (1997; 1968), de Certeau (1984) and Henri Lefebvre $(2004 ; 1991)$ to interpret the city and the artists who oppose the constructed walking spaces which manipulate the pedestrian's experience of the city. He juxtaposes the theories with the paradoxical creativity born out of opposing the state-imposed parameters for creativity. For example, Goh (2014) refers to Amanda Heng, a Singaporean artist who challenged the act of walking itself through performance art in which she chose to walk backwards with her shoes in her mouth. Additionally the author also looks at the similarities between Paris a hundred years ago and Singapore today. Goh postulates that both "are urban spaces produced by capital in different modes of geopolitical articulation" (2014, p. 26).

It is important to note that the experience of walking varies from city to city. Rajeev S. Patke in his essay 'Benjamin in Bombay? An Extrapolation' (2002), analyses how to read a city in the tropics through the concept of Walter Benjamin's flâneur. The article 'reads' postcolonial Bombay.

Patke (2002) speaks of the estrangement of the urban middle class in Mumbai (Bombay), comparing this with the estrangement Parisians felt in the Paris captured in the writings of Benjamin (1964). In drawing these parallels, the writer does not lose the sense of Asian sensibilities and very carefully throughout the paper maintains the balance between western romantic and local Indian notions of the city; reading Mumbai through a contemporary contextualisation of the flâneur. Patke (2002), a writer of Indian origins, does not escape elements of exoticism in his descriptions of postcolonial Bombay. He describes the urban sprawl and milieu of Mumbai as being extremely colorful and like an intricate piece of artwork, kaleidoscopic - a unique tapestry. Patke juxtaposes Benjamin's writings and observations with those of famous Indian writers and poets who have also written about Bombay/Mumbai. The author has also used images from daily life to give readers a sense the everyday life of the city. Patke's (2002) analysis of the city serves as an important example of one way of reading and interpreting an Asian city.

However, the way the city is perceived by a man is very different from the way it is perceived by a woman. The woman cannot take to the streets and go unnoticed; she lacks the freedom accorded to men who walk the streets. The next theme looks at the female perspective of the flâneur and the trials and tribulations women face in trying to create a relationship with the city and its sidewalks; to become a flâneuse. 


\section{The female flâneuse}

Lauren Elkin in her book, Flaneuse: Women Walk the City in Paris, New York, Tokyo, Venice and London (2017), discusses the forgotten women in history who fought to reclaim the streets; for the right to freely walk the streets without patriarchal judgments, including the negative connotations of being called a prostitute or having the male gaze reduce them to sexual objects. Moreover, Elkin (2017) includes examples of ordinary, working women who knew the stories of the streets and the city and were perceptive and receptive to the everyday rhythms of life.

While, her book is more a memoire of her walks through various cities, similar to Benjamin's (2003) peregrinations through Paris, it combines literary criticism with alternative historical facts bringing women artists and writers to the forefront - Virginia Woolf, George Sand and Martha Gellhorn, to name a few. It creates an alternative narrative and challenges the sacrosanct position of the male. However, Elkin's (2017) memoires and writings are heavily representative of cities in the global north - London, New York, Venice and Paris; only Tokyo is included as an example from Asia. The text remains based on theories of Western philosophers and feminists, thus leaving invisible knowledge from tropical cities, Eastern philosophies and feminisms.

Interesting, Elkin (2017) raises the point that the term flâneuse, which is technically the female version of the flâneur, translates, in one of its senses, as 'a piece of furniture'. She uses this notion as a metaphor for how women are treated as objects and commodities. In other words, they are subject to fetishisation as commodities, thus relating back to Walter Benjamin's critique of commodity fetishism.

Elfriede Dreyer and Estelle McDowall, in their paper 'Imagining the Flâneur as a Woman' (2012), address these key issues and challenges of walking in the city for a woman. Flânerie requires a certain level of anonymity or the ability to go unnoticed. In furthering the problematic of a female flâneuse, Dreyer and McDowall's (2012) work speaks of women's oppression as a global phenomenon. The paper looks at gender stereotyping and notes that although the concept of the flâneur is pertinent to the $21^{\text {st }}$ century, it is still not possible for a woman to freely engage in flânerie. The authors point out that women are still restricted to certain parts of the city; straying beyond the acceptable limits brings up questions regarding their character. While, in some cities, the woman of the $21^{\text {st }}$ century may not be openly subjugated, her sense of agency is still controlled and therefore she in not really free in either a mental or corporeal sense. The gendering of spaces remains a prevalent reality of the urban milieu. A woman's relationship with the city is contentious at best, and while the binary of domestication/prostitution has become less didactic, it still remains entrenched in urban consciousness. Women are thus 
relegated as representations of sin and sexuality and therefore chaos; the antithesis of the male as emblematic of order.

Dreyer and McDowall's (2012) paper concludes that to become a flâneuse and hold her own, woman needs to first fight to transcend entrenched social barriers. Currently the standards that apply to a flâneur cannot be applied to the flâneuse; thereby a woman cannot actually be a flâneur and must subscribe to separate standards to engage in flânerie.

However, to broaden the debate, Isabel Carrera Suárez, in 'The Stranger Flâneuse and the Aesthetics of Pedestrianism, Writing the Post-Diasporic Metropolis' (2015) notes that despite the challenges, women are a sentient part of the urban tapestry. In her paper she creates a space for women through an analysis of novels written by women in the $21^{\text {st }}$ century. The writers Carrera Suárez cites speak of women in modern postcolonial, post-diaspora cities, such as Singapore, Sydney, Toronto and London, as embodied pedestrians; different to the detached flâneur. Additionally, Carrera Suárez touches on the creation of a third space and how women in prose negotiate hybrid space.

Being aware of the different standards that men and women are subjected to in terms of flâneuring is essential to any study that would aspire to invoke the theory of the flâneur, and to any practice that would incorporate flânerie as a form of ethnographic method to creatively explore the metropolis.

\section{Flânerie as ethnographic method}

Ethnography encompasses a wide range of qualitative methods used to observe social practices and interactions. The act of flâneuring provides another dimension and possible depth to ethnographic field studies by aiding the process of participant observation. As Charles Soukup states, "By adopting the methodological practices of flanerie, ethnographers can provide compelling and evocative analyses of postmodern culture that make sense of the complex cultural moment" (Soukup, 2012, p. 276).

Kathryn Kramer and John Rennie Short in their paper 'Flânerie and the Globalizing City' (2011) draw links between the original conception of the flâneur, and contemporary ideas of what it means to be a flâneur in a globalized society, through sociological and artistic perspectives. They argue that the senses play an integral part in flânerie, helping people holistically engage with the changing cityscape. This was also articulated by de Certeau in his literary work "Walking in the city" (1985). 
The article by Kramer and Short (2011) acknowledges the traditional pejoratives associated with flânerie being an idle, futile practice and how these notions are changing in contemporary times to incorporate the practice as an acceptable ethnographic research method. It also examines the relation of the flâneur with art and aesthetics and the bombardment of the senses due to the kaleidoscopic nature and phantasmagoria of the city. Using photographs, the paper analyses flâneuring in cities like Barcelona and Copenhagen in Europe, as well as Shanghai in East Asia and tropical Asian cities like Mumbai. While the authors acknowledge that the flâneur remains a male concept and that very little space is given to the female flâneuse, the paper nevertheless lacks references from women scholars and their ideas on the production of space.

A similar lack of space given to the female flâneuse is evident in Chris Jenks and Tiago Neves article, 'A walk on the Wild Side: Urban Ethnography meets the Flâneur' (2000). When discussing the flâneur's gaze, they neglect to refer to the privilege of the male gaze and how women are not accorded the same freedom. Nevertheless, they examine the pertinence of the concept of the flâneur in contemporary sociological and ethnographic practices. Ethnography as a practice cannot be limited to just text and therefore walking incorporates a significant aspect of experiencing places, spaces, cultures and people. At the same time, neither does ethnography negate text. In addition to noting the importance of academic analyses, Jenks and Neves also discuss the relevance of fictional writers and their influence on the varied practices of ethnography, including: Charles Dickens, Henry Mayhew, Jack London, Jack Kerouac. However, this list of literary authors, once again, alerts us to the inherent masculine Western centrism which needs to be critiqued in the take up of flânerie in ethnographic and ethno-fictive practices.

Baudelaire's flâneur, as a work of fiction, has become synonymous with sociocultural urban change and modernity; how the flâneur walks through the city observing, gazing and critiquing is essential to the process of how an ethnographer would study the city. Though the flâneur is a dilettante and the ethnographer a scholar, it does not undermine the importance of the process of participating in and observing street life that the former embodies. An interesting point regarding this text is reference to the flâneur taking his turtle for a walk, and how this imagery is suggestive for the urban ethnographer whose methodology requires slowing down in order to observe the minutiae of everyday life on the street.

In order to further ethnographic practices, it has been proposed in much academic literature to engage photography to capture moments of creativity on the ground. 


\section{Visual flânerie through photography}

Photography is an important tool for ethnographic flânerie. It can be used to capture fleeting impressions and is usefully deployed "alongside walking in order to apprehend affective, ineffable, and mundane moments in the field" (Yi'En, 2014).

Dipesh Kharel in 'Visual Ethnography, Thick Description and Cultural Representation' (2015), explains:

Visual information, particularly images, are ubiquitous in our society. They permeate our academic work, everyday lives, conversations...our imagination and our dreams.... [I]mages are inextricably tied up with our daily life, personal identities, narratives, lifestyles, cultures and societies, as well as with the notions of history, space and truth. Ethnographic research is likewise intertwined with visual images and socio-cultural representations.... (Kharel, 2015, p.147).

The use of images is not merely as representations of the objective world; images also help communicate anthropological-ethnographic notions of "thick description", thick interpretation" and thick meaning" (Kharel, 2015). Using the metaphor of a tree Kharel (2015, p. 155) explains the interconnection of these three concepts. The "thick description" constitutes the roots of the tree that nourish and feed "thick interpretation", represented by the solid trunk of the tree, which in turn feeds the branches and leaves of the tree, which represent the "thick meaning".

However, in critique of this tree imagery (with its inherent connotations of origins, linear growth, and taxonomic branches so reminiscent of European development theories) we propose that these concepts are more intricately and finely expressed through invoking the image of the tropical banyan tree, with its rhizomatic interweaving of roots, and branches, and trunks (Lundberg 2008; 2016).

The method of ethnographic photography is exemplified in the study by Cheng Yi'En entitled: 'Telling stories of the city: Walking ethnography, affective materialities, and mobile encounters' (2014). The author describes the ethnographic process of walking in the city to encounter hidden corners of Singapore. Using photography as a method of capturing the ineffable and mundane through vignettes of the city, Yi'En acknowledges the role that walking plays in experiencing the everyday.

The author integrates the philosophical concept of phenomenology with wandering to experience the reticent everyday objects and experiences in the city. He thus reaffirms that an 
important way to experience an urban landscape is by walking through it. He offers a valuable insight on how to navigate the city and how a local may experience it.

However, it needs to be acknowledged that photography has also come under serious theoretical investigation. Baudelaire critiqued the daguerreotype, even as he maintained strong friendships with photographers and posed for many photographic portraits. Photography has also been theoretically critiqued regarding its veracity. Photographs are a representation and not reality, and, of course, photographs do not give a full picture - they are positioned, staged, posed, cropped, enhanced, manipulated. Nevertheless, they can also be an important tool for the ethnographic flâneur/ flâneuse.

Although written in 1977, Susan Sontag's famous analytical work On Photography has remained as relevant as the art of photography itself. Sontag's take on photography is very similar to the concept of Benjamin's flâneur and the flâneur's relationship with change, of nonintervention and being an observer. Sontag notes that "The person who intervenes cannot record; the person who is recording cannot intervene" (1977, p. 178). She goes on to further describe cameras as tools which aide the act of passive observing and provide the tacit explicit encouragement to keep events unfolding.

Sontag's writing captured the relationship between reality and the images that capture realities. She writes of the democratisation of experiences by translating them into images and the use of photography as a more widely accepted medium of expression and re-presentation of material experiences. Her words capture the transformation of this medium into a universal means of expression used to capture the change and the mechanics, the mundane and the beauty of everyday life. Sontag believed that "Photographs are perhaps the most mysterious of all the objects that make up, and thicken, the environment we recognize as modern" $(1977$, p. 178).

\section{A pause, to be continued...}

This perambulation through literature addressing the flâneur has sought to acknowledge classical and contemporary texts that are of use to studying the rise of the creative city. We have been particularly sensitive to two main areas of critique of the concept of the flâneur. one, that is has been based on ideas arising from studies of cities of the global north; and two, that it is male-centric. In an attempt to make the literature review more inclusive of the tropical global south and of women, we have addressed writings that help to open a space for tropical flânerie and the flâneuse tropique. As a theory and method conducive to exploratory studies on the ground we have also reviewed texts that include flânerie as part of an ethnographic repertoire for urban anthropology and related disciplines. And finally, we have addressed texts useful to the discussion and exploration of visual flânerie through the use of photography. 
Cities are undergoing enormous growth, especially pronounced in Asia and the tropical regions of the world. At the same time, cities are also undergoing a reimagining as creative spaces reliant upon creative industries and economies. In order to study and understand these changes, and to document the rise of the creative city, we propose that flânerie offers a method of observing and engaging creativity at the ground level. The metaphorical cracks in the pavement are the interstitial spaces through which local creativity may emerge.

\section{References}

Ackland, M. (2017). Review of Walking in Berlin: A Flaneur in the Capital by Franz Hessel. eTropic: electronic journal of studies in the tropics, 16(2). doi:10.25120/etropic.16.2.2017.3626

Andersson, Å. E., Andersson, D. E. (2015). Creative cities and the new global hierarchy. Applied Spatial Analysis and Policy, 8(3), 181-198. doi:10.1007/s12061-0159141-7

Baudelaire, C. (1964). The painter of modern life, and other essays. (Mayne, J., Ed. \& Trans.) London: Phaidon Press.

Benjamin, W. (1968). Illuminations (Arendt, H., Ed., Zohn, H., Trans.). New York, NY: Schocken Books.

Benjamin, W. (1997). One-Way Street (Jephcott, E., \& Shorter, K., Trans.). London, England: Verso.

Benjamin, W. (2003). The Arcades Project. (Eiland, H. \& McLaughlin, K. Trans). Cambridge Mass.: Harvard University Press.

Bhabha, H. K. (1994). The location of culture. New York \& London: Routledge.

Boutin, A. (2016). Baudelaire's media aesthetics: The gaze of the flâneur and 19th-century media. Lincoln: University of Nebraska Press.

Buck-Morss, S. (1991). The dialectics of seeing: Walter Benjamin and the Arcades Project. Cambridge, Massachusetts: The MIT Press.

Carrera Suárez, I. (2015). The stranger flâneuse and the aesthetics of pedestrianism: Writing the post-diasporic metropolis. Interventions, 17(6), $853-865$.

doi:10.1080/1369801X.2014.998259

Coates, J. (2017). Key figure of mobility: The flâneur. Social Anthropology, 25(1), 28-41. doi:10.1111/1469-8676.12381

de Certeau. M. (2011)[1984]. The Practice of Everyday Life. Berkley: University of California Press.

Dreyer, E., \& McDowall, E. (2012). Imagining the flaneur as a woman. Communicatio: South African Journal for Communication Theory and Research, 38(1), 30-44. 
Elkin, L. (2017). Flâneuse: Women walk the city in Paris, New York, Tokyo, Venice, and London. New York: Farrar, Straus and Giroux.

Florida, R. L. (2002). The rise of the creative class, and how it is transforming work, leisure, community and everyday life. New York, NY: Basic Books.

Florida, R. (2012). The rise of the creative class revisited (Tenth Anniversary Edition). New York, NY: Basic Books.

Fulford, R. (2013). Walter Benjamin, the flâneur, and the confetti of history. Queen's Quarterly, 120(1), 28

Garcia-Sanchez, S. (2013). Michele Robert's memoir: The woman flaneur experience in London. Women's Studies, 42(6), 629.

Gluck, M. (2003). The flâneur and the aesthetic: Appropriation of urban culture in mid-19 century Paris. Theory, Culture \& Society, 20(5), 53-80. doi:10.1177/02632764030205003

Goebel, R.J. (2011). Benjamin's Arcades Project today: From the European metropolis to the global city. Journal of Postcolonial Writing 47(5), 488-496. doi.org/10.1080/17449855.2011.614771

Goh, D. P. S. (2014). Walking the global city: The politics of rhythm and memory in Singapore. Space and Culture, 17(1), 16-28. doi:10.1177/1206331212451686

Goldstein, J. L. (2008). The flaneur, the street photographer and ethnographic practice. Contemporary Jewry, 28(1), 121-124. doi:10.1007/BF03020936

Hessel, F., Benjamin, W., \& DeMarco, A. (2017). Walking in Berlin: A flaneur in the capital. London, United Kingdom: Scribe Publications.

Jenks, C., \& Neves, T. (2000). A walk on the wild side: Urban ethnography meets the flâneur. Cultural Values, 4(1), 1-17. doi:10.1080/14797580009367183

Kharel, D. (2015). Visual ethnography, thick description and cultural representation. Dhaulagiri Journal of Sociology and Anthropology, 9, 147-160. doi:10.3126/dsaj.v9i0.14026

Kramer, K., \& Short, J. R. (2011). Flânerie and the globalizing city. City, 15(3-4), 322 - 342. doi:10.1080/13604813.2011.595100

Landry, C. (1994). The Creative City: A Toolkit for Urban Innovators. New York, NY: Earthscan.

Laschinger, V. (2009). Flaneuring into the creative economy: Orhan Pamuk's Istanbul: Memories of a city. The Explicator, 67(2), 102-105. doi:10.3200/EXPL.67.2.102-105

Lauster, M. (2007). Walter Benjamin's myth of the flaneur. The Modern Language Review, 102(1), 139-156.

Lefebvre, H. (1991). The production of space (Nicholson-Smith, D., Trans.). Malden, MA: Blackwell

Lefebvre, H. (2004). Rhythmanalysis: Space, time and everyday life (Elden, S., Moore, G., Trans.) 
Lundberg, A. (2008). Material poetics of a Malay house. The Australian Journal of Anthropology, 19(1), 1-16. 10.1111/j.1835-9310.2008.tb00102.x

Lundberg, A. (2016). Rhizomes, Weak Links and Far Flung Networks: Empowering women's space in Tropical Asia. eTropic: electronic journal of studies in the tropics, 15 (2), 106117. DOI: http://dx.doi.org/10.25120/etropic.15.2.2016.3547

Mallan, K. (2012). Strolling through the (post)modern city: Modes of being a flâneur in picture books. The Lion and the Unicorn, 36(1), 56-74.

National Arts Council. (2000). RENAISSANCE CITY REPORT: Culture and the Arts in Renaissance Singapore. Retrieved from National Arts Council website: https://www.nac.gov.sg/dam/jcr:defaf681-9bbb-424d-8c77-879093140750

Patke, R. S. (2002). Benjamin in Bombay? An extrapolation. Postmodern Culture, 12(3), 35. doi:10.1353/pmc.2002.002

Sontag, S. (1977). On Photography. New York: Picador USA.

Soukup, C. (2012). The postmodern ethnographic flaneur and the study of hyper-mediated everyday life. Journal of Contemporary Ethnography, 42(2), 226-254. doi:10.1177/0891241612461278

Vainshtein, O. (2017). Walking the turtles: Minimalism in European dandy culture in the nineteenth century. Fashion, Style \& Popular Culture, 4(1), 81-104.

doi:10.1386/fspc.4.1.81_1

Watson, P. (2005). The city, the flaneur and the man with the camera. West Coast Line: $A$ Journal of Contemporary Writing \& Criticism, 39(2), 42.

White, E. (2001). The flaneur: A stroll through the paradoxes of Paris (1st U.S. ed.). New York: Bloomsbury.

Wolfe, C. R. (2017). Seeing the better city. How to explore, observe, and improve urban space. Covelo: Island Press.

Wrigley, R., \& Wrigley. (2014). The flâneur abroad: Historical and international perspectives (1st ed.). Newcastle-upon-Tyne: Cambridge Scholars Publishing.

Yang, C. L. (2012). T.S. Eliot's virtual Europe: The flaneur and the textual flanerie. Yeats Eliot Review, 29(3-4), 3.

Yi'En, C. (2014). Telling stories of the city: Walking ethnography, affective materialities, and mobile encounters. Space and Culture, 17(3), 211-223. doi:10.1177/1206331213499468 